\title{
SOCIOLOGICKÁ IMAGINACE DNES: HLEDÁNÍ NOVÉHO PŘíBĚHU
}

\author{
KAREL HLAVÁČEK \\ Katedra sociologie Filozofické fakulty Ostravské univerzity \\ E-mail: karel.hlavacek@osu.cz
}

Charles Wright Mills napsal svou Sociologickou imaginaci, manifest o roli sociologie jako nástroje podporujícího politickou představivost občanů, před 60 lety. A jako každé výročí i toto představuje dobrou příležitost pro reflexi toho, co nám může Mills říci dnes, čím je pro nás ještě aktuální, a naopak, co z jeho dědictví je třeba opustit. Tato otázka je ovšem složitější: je spjata s tázáním se po tom, jak se za oněch 60 let změnila doba a s ní i sociologie. Jen tehdy, když si uvědomíme, kde dnes stojíme, budeme moci říci, kam se odsud v návaznosti na Millse vydat a co raději nechat stranou.

Hlavní změnou oproti situaci z roku 1959 je to, že tehdejší kontext je možné označit za moderní, kontext roku 2019 je ale postmoderní. Mills sice ve svém textu hovoří o konci modernity, nikoli ale v dnešním smyslu. Nakrátko se sice zdá, jako by modernitu zpochybňoval, když problematizuje vztah rozumu a svobody, jeho snahy nicméně nakonec ústí pouze do odlišení částečné „racionality“, která je nebezpečím, a pravého „rozumu“, o nějž nám nadále jde. Př́íslib sociálních věd tak stále spočívá v „uchování rozumu a svobody“ (Mills, 2002, s. 188). Mills se v úzké vazbě na osvícenskou tradici snaží vytvořit variantu obecné sociologické metateorie a jako základ využívá jen mírně upravený př́iběh o rozumově dosažené svobodě. Sociologie stále hraje svoji roli v rámci tohoto „velkého prríběhu“.

Tím postmoderna otřásla více do hloubky: dnes si skutečně nejsme jisti, zda užití rozumu nějak přispívá k nárůstu svobody. A to i tehdy, hovoří-li se skutečně o onom „pravém“ rozumu, nikoli jen o jakési částečné racionalitě. V tomto textu vycházím z následujícího: užití rozumu svobodu nezaručuje a rozum, nenachází-li se v patřičném kontextu (jak tvrdím níže, např. v kontextu moudrosti či víry), může být nebezpečný. To ovšem kreslí nad ideou „sociologické imaginace“ velký otazník: vždyt neměla být ničím jiným, než použitím rozumu pro analýzu společenské situace.

Otazník visí i nad tázáním po smyslu sociologie jako celku. Dnešní postmoderní vědomí je vědomím fragmentárnosti a projevuje se jako antisystémové. Můžeme ještě mít nějaké jednotné rámování toho, co znamená sociologie? Nejspíše ne: pokud bychom přitakali Millsovi a prosazovali angažovanou sociologii, neutlačíme tím ty proudy, které sociální angažovanost odmítají? Ale i v rámci samotné angažované (či radikální či kritické) sociologie: je možné vyhlásit nějakou její jednotu? Odpovědí je opět spíše „ne“.

Dalším rozdílem mezi rokem 1959 a 2019 je to, že dnes pomalu vstupujeme (a, jak se domnívám, vstupovat bychom měli) do doby „postsekulární. Mills si před 60 lety byl stále ještě jist př́během rozumu. Vyloučeno zůstávalo to, co bylo považováno za rozum překračující či dokonce jemu protikladné. Protikladem rozumu byla typicky „víra“, ale 
„rozum“ transcendovala i např. „moudrost“. Mills v návaznosti na osvícenskou tradici netouží po „moudrosti“ ani se netáže po správné „víře“.

To je dnes, domnívám se, navýsost sporné. Postupně se začíná ukazovat, že „víra“ není protikladem rozumu, nýbrž spíše patří do oblasti jeho předpokladů. Stejně tak se začíná zdát, že „rozum“ je zřejmě prospěšný svobodě jen tehdy, jestliže vychází z moudrosti a je užíván pro hledání moudrosti. V postmoderní radikalizaci kritiky modernity známé z Dialektiky osvícenství se dnes lze domnívat, že to byl oddělený rozum, který natropil v nedávných dějinách tolik škod. V západní tradici ale existují kromě „rozumu“ ještě dvě výše zmíněné ideje, ze kterých je možno čerpat: jsou to právě moudrost, ke které se obraceli antičtí myslitelé, a víra, která byla horizontem středověkým vzdělancům. Sociologická imaginace, chce-li být intelektuálně upř́mná, už dnes nemůže disponovat jistotou, že obě tyto tradice překoná izolací jejich jediného prvku, rozumu. ${ }^{1}$

První z výše nastíněných společenských změn (tj. příchod postmoderny) je do dnešní sociologie hluboce začleněna. Sociologie je dnes z velké části postmoderní. Nikoli v tom smyslu, že by sociologové z valné většiny byli přesvědčenými postmodernisty; spíše se obor nachází v postmoderní situaci. Je fragmentarizovaný, postrádá jednotné zarámování a „velká teorie“, kterou kritizoval Mills, je dnes mrtva. Zvláštně se v tomto kontextu jeví i samotná Millsova kniha, protože se v ní autor ještě táže na celek sociologie a zasazuje ho do varianty osvícenského příběhu. Postmoderní duch je ale vůči takovému počínání podezřívavý. Jednota smyslu, kterou před nás Mills ve své knize staví, se může jevit jako nostalgie, jako beznadějná touha po něčem definitivně ztraceném.

Druhá změna (tj. „postsekularita“) ovšem vstřebána dosud nebyla - představuje teprve se formující program, který obor jen pomalu a postupně začíná vnímat, pokud ho vůbec vnímá. ${ }^{2}$ Pro většinu sociologů by se i dnes hovory o „moudrosti“ či dokonce „víře“ jako o čemsi, na čem sociologie stojí či na čem by stát měla, jevily jako absurdní. Nezajištuje snad sociologie „věděni““ jako protiklad „víry“ a nejsou otázky týkající se „moudrosti“ daleko za horizontem toho, na co se sociolog může tázat?

Není tomu tak. Víra či moudrost (či jejich absence) nejsou čímsi, co k sociologii přistupuje jaksi dodatečně nebo co by pouze zkoumala u ostatních lidí. Jsou součástí metafyzického podkladu, ze kterého sociologie teprve vyrůstá (či v tomto podkladu absentují). Vždyt’ dnes přece spolu s Heideggerem víme, že věda není protikladem metafyziky, ale zdrojem a současně plodem jedné svébytné podoby metafyziky. ${ }^{3}$ Víme tedy, že ani sociologie jako specifická podoba vědy se od metafyziky nikdy neoddělila a možná oddělit

1 Zde odkazuji na „postsekulárni“ projekt, který před nás staví postmoderní americký filosof náboženství John D. Caputo (2001). Ten se pokouší právě o inspiraci ve všech třech klíčových obdobích naší civilizace: $\mathrm{v}$ antice (hledání moudrosti), ve středověku (křestanská víra) i v modernitě (rozum, individuální práva, rovnost). Rozum zde má být př́tomen, ale jen jako jedna integrální část širšího kontextu. Izolovaný rozum Caputo považuje za „pošetilýc v augustinovském smyslu (2001, s. 39-40).

2 Nejvýraznější postavou, která je v sociologii známa a současně prosazuje typ postsekulárního přístupu, je Jürgen Habermas, který s příchodem 21. století přehodnocuje svůj vztah k náboženství (napřr. Habermas, 2008); radikálnějš́i je v tomto směru jiná známá postava, Charles Taylor. Další verze postsekulárního př́stupu představují postmoderní nábožensky orientovaní autoři (Gianni Vattimo, John D. Caputo či Richard Kearney) či hnutí Radikální ortodoxie vlivného teologa a filosofa Johna Milbanka. Uvnitř sociologie v užším smyslu (vždyṫ jak Habermas, tak Taylor mohou být bráni jako filosofové; ostatní prominentní postavy zastávající postsekulární postoje jsou vyloženě filosofové či teologové) pak dosud nacházíme spiše izolované př́íspěvky než ucelená pojetí.

3 Heidegger pojímá metafyziku jako místo, kde se rozhoduje o epistemologických a ontologických předpokladech, resp. o povaze pravdy a povaze jsoucna: „V metafyzice dochází k zamyšlení nad bytností 
ani nemůže: může jen své metafyzické kořeny zakrýt, a stát se tak nevědomou. Jakékoli obecné zamyšlení nad sociologickým oborem tak dnes musí znovu tematizovat metafyzický rámec, ze kterého sociologie vyrůstá. První otázka, která dnes musí být položena $\mathrm{v}$ jakémkoli pojednání o tom, co sociologie je, by měla znít: v rámci jakého prŕběhu má sociologie své místo? V rámci jaké metafyziky dává smysl, abychom sociologii vůbec vytvářeli?

Millsova metafyzika se stále do velké míry opírá o klasická osvícenská pojetí, jakkoli Mills výrazně upozorňuje na problém dílčí racionality, která se může zvrhnout. Sociologická imaginace hraje roli uvnitř př́běhu o člověku, který se silou rozumu politicky emancipuje z područí nesvobody. Spolu s nejasnostmi ohledně role rozumu je pak ale zpochybněna i sociologická imaginace jako taková. V postsekulární chvíli, kdy už je možno „rozum“ rozpoznat jako jednostrannou novověkou dekontextualizaci starších idejí, je možno se znovu obrátit i ke starší tradici: neměla by sociologie - aniž se vzdá rozumu - svojí angažovaností napomáhat růstu moudrosti nebo dokonce víry? ${ }^{4}$ Nemohla by sociologická imaginace přinést svoje plody i v rámci jiných př́běhů než je ten osvícenský? Nebo: jakou podobu má mít sociologie za hranicí osvícenství, jakou podobu má získat v situaci postmoderní fragmentarizace a na počátku postsekulární debaty?

Postmoderní situace je stavem ochabnutí: jednota smyslu se zdá být nedosažitelná a obecné tázání, jak ho vidíme ještě u Millse a jak ho nastiňuji výše, donkichotské. Jak říká Bauman: „[společnost] postrádá smysl, ačkoli je zárukou každého smyslu, sama je bezcílná, ačkoli je zdrojem všech cílư (Bauman, 2002, s. 122). Co zbývá, jak předvídá už Lyotard, nejsou „velké příběhy“, nýbrž jen měřítka performativity (Lyotard, 1993, s. 148). Sociologie se dnes často neodvozuje z žádné jednoty smyslu, neodvozuje se od otázky, co sociologie je a k čemu zde je. Odvíjí se z mocensko-ekonomických poměrů, z toho, na co se seženou peníze a co vlivní považují za důležité. Právě proto sociolog, který se táže na smysl sociologie, dnes připomíná dona Quijota, jenž v mlýnech vidí obry a v ovcích rytíre. Sociologie nemusí mít žádný hlubší smysl: jejím smyslem může být př́iští publikovaný článek, za který dostaneme body a peníze, nic více. Toto je bezesporu dystopický obraz podoby sociologického oboru, nikoli reálný stav, v postmoderní situaci je ale takový obraz navýsost aktuální.

Bez snah o obnovení smyslu, z něhož čerpá, obor nemůže nadlouho přežít. Sociologie musí mít smysl, který překračuje pouhou mocensko-ekonomickou manipulaci, at' už míníme prostou performativitu, anebo sofistikovaněji heideggerovský „Gestell“, úhel pohledu, ve kterém se společnost a svět mění v sumu využitelných stavů. Obrovskou a snad vůbec největší inspirací Millsova textu je proto to, že se vůbec ještě táže po smyslu oboru za hranicemi těchto úpadkových tendencí.

Millsova modernita ještě měla energii mládí: chtěla něco činit a chtěla k tomu mít silné důvody. Z jejích trosek, které zveme postmoderna, nelze povstat jinak než znovuobjevením této mladistvosti: nalezením nového důvodu, proč sociologii vůbec dělat. Postmo-

jsoucího a rozhoduje se v ní o bytnosti pravdy“ (Heidegger, 2013, s. 7). Metafyzické předpoklady $\mathrm{v}$ tomto smyslu tedy samozřejmě obsahují všechny sociologické studie.

4 To nemá znamenat žádný návrat do temnot dávnověku. Jak už bylo naznačeno, projekt, ke kterému se tento text hlásí, není antimoderní; spíše chce modernitu situovat do určitého kontextu tak, aby zachovala svůj důraz na rozum, ale zbavila se své „pošetilosti“ (Caputo, 2001, s. 39-40). 
derní vědomí, skutečnost, že takový důvod nebude nikdy bezrozporný a jednoznačný, je paradoxem, který je tř̌eba unést. Ptát se musíme, i když jednoznačná odpověd’ nemůže přijít. Otázka po smyslu celku musí přetrvat, i když jsme opustili představu, že najdeme nějakou jednotnou nebo definitivní odpověd'.

V návaznosti na Millse je tedy třeba obnovit tázání po smyslu sociologie jako celku, a to přes to, že si lépe než Mills uvědomujeme paradoxní povahu takové otázky. Přitom se ale nepotýkáme s „velkou teorií“ a vlastně ani „abstraktním empiricismem“ jako Mills. „Velkou teorii“ postmoderna zničila a „abstraktní empiricismus“ sice nadále kvete, ale je pouze jedním sociologickým proudem. Současné neblahé trendy v sociologii mnohem lépe popisuje Bergerův postřeh o dvojím vývoji: o posilování „metodologického fetišismu“ a paralelní levicové ideologizaci (2003, s. 177).

Postmoderní situace je z jednoho úhlu pohledu situací excesivní a současně nedostatečné kritiky v rámci sociologického oboru. Tázání po celku nelze obnovit, protože každá odpověd’ by byla př́liš náchylná na kritiku. S tím má sociologie bohaté zkušenosti. Právě kritika zničila parsonsovskou velkou teorii, vưči níž se i Mills tolik vymezoval. Velká teorie je totiž spojena s velkými ambicemi, chce popsat společnost jako celek. A tam, kde je velká ambice, tam se kritizuje snadno. Jakákoli syntetizující teorie se kritice jeví tak partikulární, tak jednostranná, tak neoprávněně ambiciózní, že ji s přehledem destruuje. Kritika se neprojevuje jako zkvalitňující síto, ale spíše jako pouhá destrukce.

Postmoderní kritika ale zasáhla i „abstraktní empiricismus“. Tam, kde se dříve mohlo hovořit o „neutralitě“, „objektivitě“, či „bezhodnotovém“ př́ístupu, nezůstal kámen na kameni. Dnes kvantitativní sociologové - jež má Mills na mysli, když o „abstraktním empiricismu“ hovoří - bez rozpaků přiznají, že nejsou ani neutrální, ani objektivní, ani bezhodnotoví. Na rozdíl od velkých teoretiků ale po tomto přiznání o to pilněji pokračují v práci. Postmoderní kritika, která zcela zničila velkou teorii, „abstraktní empiricismus“ nedestruovala, nýbrž ho posílila.

To se může jevit jako paradoxní, ve skutečnosti je to ale logické: velká teorie byla nerozlučně spojena s velkou ambicí, ale „abstraktní empiricismus“, jak viděl už Mills, k žádným velkým ambicím vázaný není (2002, s. 62). To se projevuje i dnes. Výzkum lze provést, at už je výsledek považován za „objektivni“ anebo ne. Výzkumník může snadno pokrčit rameny a říci: „Dobře, ukázali jste mi, že domněnka o ,neutralitě a ,bezhodnotovém př́stupu' je mylná. No a co? Neztrácejme čas planým teoretizováním a dejme se do práce!" 5

Ale i abstraktní empiricismus se v reakci na kritiku změnil. Kritika vždy kritizuje to, co se ke kritice nabízí. Abstraktní empiricismus tak pracuje na tom, aby v rámci jeho předpokladů nebylo možno kritizovat pokud možno nic. Pracuje na tom, aby metoda byla co nejpreciznější. Ostatní důrazy - jako jsou důležitost a dosažnost otázky, kterou si sociolog klade, obsažnost a zajímavost jeho tezí atp. - musely ustoupit.

Sociologii tak dnes trápí jiný problém než v době Millsově: neustále se zostřující kritika, která celou sociologii přetváří z projektu zaměřeného na porozumění společnosti na podnik zaměřený na prevenci kritizovatelnosti. Přežívají jen takové sociologické směry,

5 Takto se často implicitně postupuje v praxi. Explicitně s takovým postojem přichází např. americký sociolog Jonathan H. Turner, jeden z mála současných obhájců pozitivismu. 
které si dokáží předepsat dostatečně účinnou preventivní kúru proti kritice. To velká teorie nemůže dokázat z definice. Abstraktní empiricismus naopak v takovém prostředí kvete: snahu o co největší metodologickou preciznost bez větších teoretických ambic má vepsanou v DNA.

Avšak abstraktní empiricismus je jen jedním sociologickým proudem - velkou afinitu k němu má kvantitativní sociologie. Stejně dobře ale lze stále precizovat metodologie kvalitativní. Sociologii tak dnes neovládá abstraktní empiricismus, ale spíše obecněji míněný bergerovský „metodologický fetišismus“. Ten je logickým důsledkem procesu postupného zostřování kritiky, které nezná žádné hranice a postrádá kritiku kritiky: chybí postkritické vědomí.

Millsova kniha nám připomíná, jak mylné je zaměřovat se na pouhou preciznost a předcházení kritiky a jak sporné je nechat se určovat metodou. Vychází z pocitované potřeby dosahovat větší svobody, nikoli z imperativů metody. A s precizností si hlavu neláme. Každý sociolog toužící po preciznosti se tak zamračí už při přečtení první věty jeho knihy, kde se hovoří o pocitech nespecifikovaných mnoha lidí, aniž by toto východisko bylo opřeno o data. Hodnota publikace očividně nespočívá v preciznosti - naopak ukazuje, že přetrvávající vliv může získat i kniha, která by dnes byla nejspíš hodnocena jako „pouhý“ esej.

Pokud chceme znovu získat odvahu ke kladení obecných otázek, musíme být především kritičtí vưči kritice a vůči metodě. Kritizovat v rámci metody je jednoduché a kdo hledá, vždy najde, co by zkritizoval. To se také děje. Sociologie se pak stává projektem předcházení kritiky v rámci předpokladů daných metodou. To, co pak nakonec zůstává kritikou nedotčeno, je oblast předpokladů metody a s ní i mocensko-ekonomické poměry, což je z hlediska každé „radikální sociologie“ snad nejzávažnější. Vždyṫ zavedené metody mohou být do velké míry produktem těchto poměrů. Ne náhodou Mills konstatoval, že určité druhy sociologie (právě ty, které shrnoval pojmem „abstraktní empiricismus“) se mnohem lépe hodí pro potřeby administrativního aparátu než pro potřeby pěstování sociologické imaginace (2002, s. 61). ${ }^{6}$

Kromě prŕlišné důležitosti přisouzené metodě a kritice v jejím rámci nacházíme v sociologickém oboru ještě jeden zdroj neblahých tendencí. Jedná se o převážně levicově orientované politické naděje, které se ideologizují. ${ }^{7}$ Takové ideologizující se naděje ostatně reprezentuje i Mills a jeho idea sociologické imaginace.

V této souvislosti se může zdát zvláštní, že se v sociologii může vyskytnout i zdánlivě opačná tendence než je úzkostlivá metodologická preciznost. Jedná se ovšem pouze o zdánlivý paradox. Kritika se vždy uplatňuje v rámci určitých předpokladů, předpoklady samy ale nemusí zasáhnout. Ba je ani zasáhnout nemůže, pokud jsou předpoklady

6 To je možné proto, že stávající mocensko-ekonomické poměry zformovaly celý rámec, ve kterém „abstraktní empiricismus“ dává smysl. Metafyzická otázka, která se táže, co je společnost a co je sociologie, (a tedy i: co je „jsoucno“ a co je "pravda“) jsou tu předem dány a jsou formovány potřebami administrativy. Společnost se zde jeví jako suma popsatelných a v posledku manipulovatelných faktů a sociologie jako nástroj, který tato fakta popisuje. Proti tomu by ovšem Mills protestoval. Pro něho se společnost jeví jako kolbiště, ve kterém si občané vybojovávají svobodu a sociologie jako nástroj, který jim pomáhá rozumět sobě samým.

7 O tomto pojednává americký sociolog Christian Smith. Nepřekvapí, že za „posvátný projekt“ americké sociologie (tezi by ovšem šlo jednoduše rozšriřit i na evropskou sociologii) považuje „odhalení a ukončení lidské nerovnosti, vykořistování, utrpení, nespravedlnosti...", tj. právě levicově orientovaný projekt (Smith, 2014, s. 7). 
položeny jako axiom. A právě $\mathrm{k}$ tomu dochází: (nejčastěji) levicové hodnoty jsou do sociologie vsouvány jako axiomy předem, zejména volbou teoretického zázemí, tématu a způsobem položení otázky. Pak už jsou dokořán otevřeny dveře $\mathrm{k}$ využití sociologie pro politický boj.

Ideologické využití sociologie je možné, protože nadměrná kritika je povětšinou silně jednostranná: trestají se metodologické nedostatky, ale ideové kořeny a předpoklady, ze kterých sociologický produkt vyrůstá, zůstávají nedotčené. Má se za to, že jsou věcí víceméně libovolného výběru. Tím se podporuje omezení reflexe předpokladů, které potom mohou zkamenět v nereflektované předsudky. Kritika je současně nadměrná i nedostatečná.

Výzkumy pak mohou být sebeprecizněǰí, ale ve skutečnosti slouží pouze ke kruhovému potvrzení původních předsudků. Jestliže se např. ptáme na diskriminaci minoritních společenských skupin, odpověd na tuto otázku je předem daná. Tyto skupiny diskriminovány jsou. Výzkumem jsme dosáhli preciznější formulace toho, co bylo beztoho jasné, tj. dosáhli jsme pouze potvrzení původního předpokladu (Horák, 2017, s. 132). ${ }^{8}$ A to $\mathrm{v}$ tuto chvíli ani není řeč o metafyzicko-náboženských předpokladech, které se většinou krčí v neprůhledném pozadí výzkumu a tiše doufají, že budou přehlédnuty. Takový výzkum se pak sice velice dobře hodí k využití pro politický boj, ale je méně vhodný pro hlubší rozvoj oboru.

K ideologizaci bohužel tíhne právě kritická a angažovaná sociologie; stejná tendence je koneckonců obsažena i v Millsově radikální sociologii. Sociologická imaginace je vzdělanostní kompetence, která svému nositeli umožňuje použít „rozum“ pro účely aktivní participace na politickém boji, kde si může vybojovat více „svobody“. Je-li ale sociologie primárně nástrojem v politickém boji, pak je právě politický boj horizontem, ve kterém sociologie jedině dává smysl. Sociologická imaginace ho ničím nepřekračuje, zůstává mu podřízena, odehrává se $\mathrm{v}$ jeho rámci. Nakonec tak bude sloužit partikulárním politickým zájmům, které s její pomocí budou precizněji formulovat to, co od začátku prosazovaly jako svoji pravdu.

Vratme se k př́kladu, který popisuje výše citovaný Horák, ke společenským menšinám: ty budou za pomoci sociologické imaginace kolem dokola stále precizněji tvrdit, že jsou diskriminovány, a i když budou mít pravdu a s jejich touhou po emancipaci lze sympatizovat, nelze souhlasit s tím, že to, co jim pomáhá formulovat jejich politický zájem, je správná podoba sociologie.

Německá kritická tradice o tomto problému věděla lépe než Mills. První generace frankfurtské školy, zejména Theodor W. Adorno, Max Horkheimer či Walter Benjamin nebezpečí ideologizace viděli jasně a $v$ boji proti tomuto nebezpeční se plodně inspirovali v judaismu. Ve společenské kritice těchto autorů zůstává zachován negativní smysl náboženské kritiky idolatrie. Např. u Adorna se na společnost hledí z úhlu pohledu „vykoupení (Erlösung). ${ }^{9}$ Vykoupení přitom není pouze alegorií nějaké hodnoty, jako

8 Horákově (2017) skvělé analýze postmoderních podmínek sociologického oboru (stejně jako mnoha rozhovorům s ním) jsem vděčen za více, než vyjadřuje jedna citace. V určitém smyslu stojí celý tento esej na diskusi s ním - pouze vyhlídka na řešení, které já osobně hledám v postsekulárním přístupu, je odlišná od jeho „hermeneutického“ porozumění úkolu sociologie.

9 „Filosofie, kterou lze tvář́ v tváŕ zoufalství jedině ospravedlnit, by byl pokus pojímat všechny věci tak, jak by se ukazovaly z hlediska vykoupení. Poznání nemá žádné jiné světlo než to, které na svět dopadá Z vykoupení: vše ostatní se vyčerpává v dodatečné konstrukci a zůstává kusem techniky“ (Adorno, 
jsou emancipace nebo rovnost; není vůbec heslem, které by bylo zneužitelné v politickém boji. Hraje stejnou roli, kterou najdeme u judaistické ideje Boha: má zabránit ztotožnění sociologického projektu s jakoukoli hodnotou a tím zabránit její ideologizaci. Stejně jako vyznavač judaismu nebo křestanství nesmí postavit žádnou hodnotu na místo Boha, Adorno nechce postavit žádnou hodnotu na místo „vykoupení. Je si vědom, že kdyby tak učinil, jeho kritika se stane „kusem techniky“, instrumentální mocenskou machinací.

Sociologická imaginace je slabá právě tím, že v sobě neobsahuje žádnou takto silnou zábranu před ideologizací; nezná rozdíl mezi realizací „hodnoty“ a „vykoupením“. Realizace hodnoty je mocenskou technikou. Proti utlačivé moci se tu bojuje utlačivou mocí. Sociologická imaginace se tak může stát vehiklem ideologie a s ní spjatého politického boje. Vždyt jak snadno se zde sklouzne od touhy po „vykoupeni“ $k$ touze po pouhé emancipaci a rovnosti!

Jakmile ale dojde $\mathrm{k}$ takové redukci, zanikne dialektika společenského procesu, který má vést k vytouženým hodnotám; zmizí rozdíl mezi nedosažitelným ideálem a společenskou realitou. Dojde pak k jevu, který judaismus a křestanství nazývaly modloslužbou. Bůh je v judaismu i v křestanství (mimo jiné) „zcela Jiný“ než lidské představy. Jasná představa, která se politicky prosazuje, se mění v modlu a postupně převrací smysl toho, oč se bojovalo. V adornovsko-horkheimerovské dikci: vzniká nová „dialektika“, ve které zjistíme, že jsme místo kupředu kráčeli zpět, že jsme namísto svobody dosáhli nového barbarství.

Do jakého př́iběhu tedy sociologickou imaginaci zasadit, aby nedocházelo ke skluzu do ideologie? Žádnou odpovědí nedisponuji; otázka ostatně přesahuje rámec tohoto eseje. Př́ležitostí k hledání nových inspirací nicméně může být výše zmíněná postsekulární debata, ze které mohou místo jednoho velkého smyslotvorného příběhu vzejít př́iběhy pluralitní. Ty musí v první řadě opustit sporný vztah „rozumu“ a „svobody“, který ještě Mills neproblematizuje dostatečně.

K tomu nám může pomoci i Millsova sociologická imaginace. Ta chce rozpoznávat průsečíky biografie a historie. Nuže: může nám pomoci rozpoznat, že sekulární protiklad rozumu a víry, kterému dodnes věří mnoho sociologů a filosofů, není nějakou metafyzickou pravdou, ale náhodnou historickou konstrukcí, která se jevila věrohodnou v určité etapě dějin, nikoli však dnes. Není už důvodu, proč tuto konstrukci nechat ovlivňovat naše biografie. ${ }^{10}$ Otevřený horizont, který se před námi po tomto uvědomění uvolňuje, je příslibem, že sociologická imaginace skutečně otevírá prostor svobody, jak chtěl Mills.

Millsova Sociologická imaginace je dnes do značné míry přežitým textem. Zůstává však upozorněním, že navzdory postmodernímu ochabnutí je nutno se nadále ptát po širším smyslu sociologie. Stojíme znovu na začátku: musíme hledat nový příběh, ve kterém sociologická imaginace jakožto lidská schopnost dává smysl. Příběh, který opustí jednostrannou ideu rozumu a současně si bude do větší hloubky vědom nebezpečí ideologizace, jemuž čelí každý politický boj.

2009, s. 244). Adornovo „vše ostatni“ bohužel s logickou nutností zahrnuje i Millsovu sociologickou imaginaci.

10 Obsažnou analýzu historické podmíněnosti a mylnosti tohoto protikladu poskytl Charles Taylor ve svém Sekulárním věku (2007). 


\section{LITERATURA}

Adorno, T. W. (2009). Minima Moralia: Reflexe z porušeného života. Praha: Academia.

Bauman, Z. (2002). Úvahy o postmoderní době. Praha: Sociologické nakladatelství (SLON).

Berger, P. L. (2003). Pozvání do sociologie: Humanistická perspektiva. Brno: Barrister \& Principal.

Caputo, J. D. (2001). On Religion: Thinking in Action. London / New York: Routledge.

Habermas, J. (2008). Between Naturalism and Religion: Philosophical Essays. Cambridge / Malden: Polity.

Heidegger, M. (2013). Věk obrazu světa. Praha: Oikoymenh.

Horák, V. (2017). Společnost jako otázka: Hermeneutický pohled na sociologii. Brno: Centrum pro studium demokracie a kultury (CDK).

Lyotard, J. F. (1993). O postmodernismu: Postmoderno vysvětlované dètem, Postmoderní situace. Praha, Filosofický ústav AV ČR.

Mills, C. W. (2002). Sociologická imaginace. Praha: Sociologické nakladatelství (SLON).

Smith, C. (2014). The Sacred Project of American Sociology. New York: Oxford University Press.

Taylor, C. (2007). A Secular Age. Cambridge / London: The Belknap Press of Harvard University Press. 